\title{
定時制女子高校生の Flicker 値の逐日変動について \\ Daily Changes of Flicker Value of Girls in Evening Classes of the Higher Secondary School
}

\author{
久留米大学医学部衛生学・環境举生学教室 (主任 安倍弘毅教授) \\ 吉 嗣 国 男 \\ Kunio Yoshitsugu \\ Department of Environmental Hygiene, Kurume University School of Medicine \\ (Director: Prof. K. Abe)
}

\section{第 1 章 緒言}

定時制女子高校生にして昼间事務勤務者について，夏 休後新学期開始とともに昼間事務及び夜間授業がもたら 寸疲学状况を研究するため，Flicker test を行つて逐日 経過につれての变動をみた。即ち新学期開始後 1 カ月に わたつて Flicker 値の变動をみてて，夜間授業に慣れる につれて正常に近つく経過をみた。

\section{第 2 章 被検者及び研究方法}

\section{I) 被検者}

定時制女子高校生にして㡺間事務勤務者 (18～19 藏) 10 名につき，昭和 29 年 9 月の 1 カ月間の経過を Flicker 值測定機を使用して行つた(なお事務勤呀場所は大 学研究室)。また夜間授業は 17 時 30 分から 20 時 40 分 までである。

II) 研究方法 ${ }^{1,21,21-111}$

1）測定は労研式 Flicker 值測定機を使用，作業前 值は 8 時 30 分 9 時, 作業後值は 16 時 30 分〜 17 時に
行つた。たたし土矅日は半どんのため作業後値は12時 30 分〜13 時まで，日网及び祭日は休日のため測定を行 わなかつた。

2）作業前值は第 1 作業日をとり，各週の休日の翌 日の週間低下をみた。

3）作業前值の日間变動と週間变動との関係につい てみた。

4）下值の逐目経過は被模者 4 名について行つた。 な拈 $\mathrm{F}$ 值は下降法により 3 回測定，その平均をとつた。

\section{第 3 章 各 論}

\section{I) 作業前值の週間変動”}

第 1 作業日の作業前のF值の週間变動をみれば，第 1

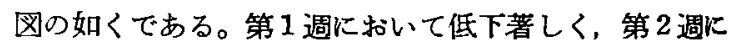
入りやや上昇を示し，第3～第 4 週に至り 正常に近つく 傾向をみた。また第 1 作業日の作業前の値を 100 として 第 2 週以下の作業前値を\%として表わすと，第 2 週の平 均は $79.8 \%$ ，第 3 週の平均は $92.1 \%$ ，第 4 週の平均㤌 $98.9 \%$ ，第 5 週の平均は $100.5 \%$ となる。これについ

第 1 図作羓前值の週間変動 (F 值)

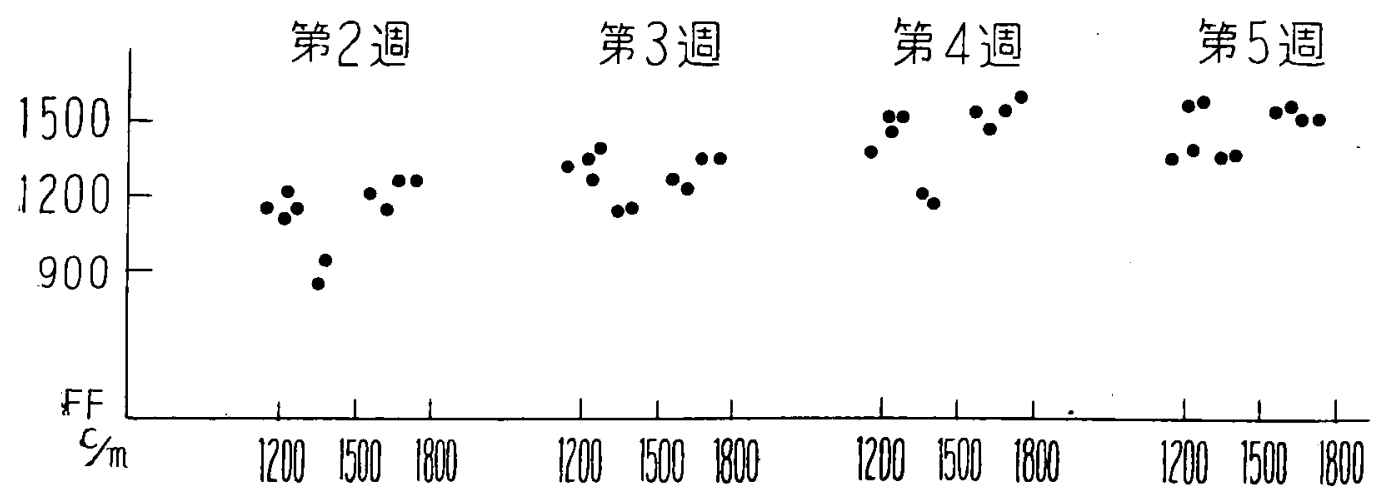


第 2 图 F值の日問変動と週間变動との関係

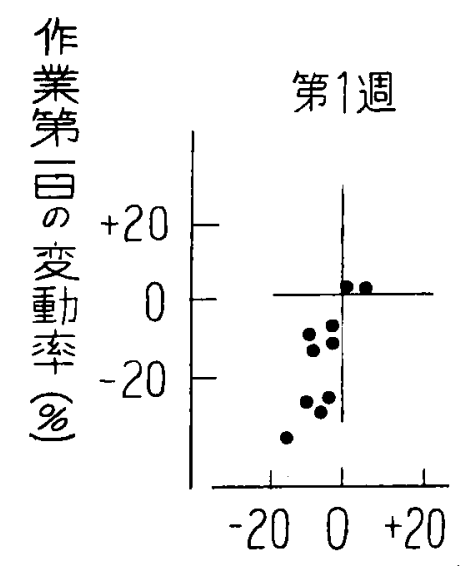

第2週第了週

第4週
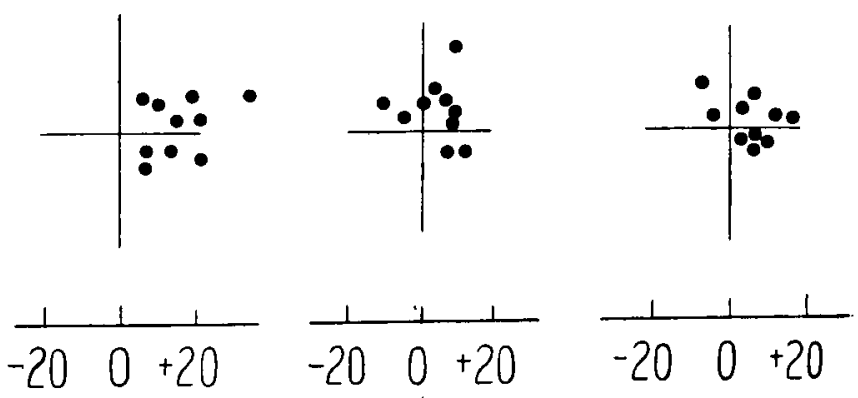

週末の作業後値の变動率 (\%)

第 3 四作業前值の逐日経過曲線（被検者 4 名，昭和 29 年 9 月）

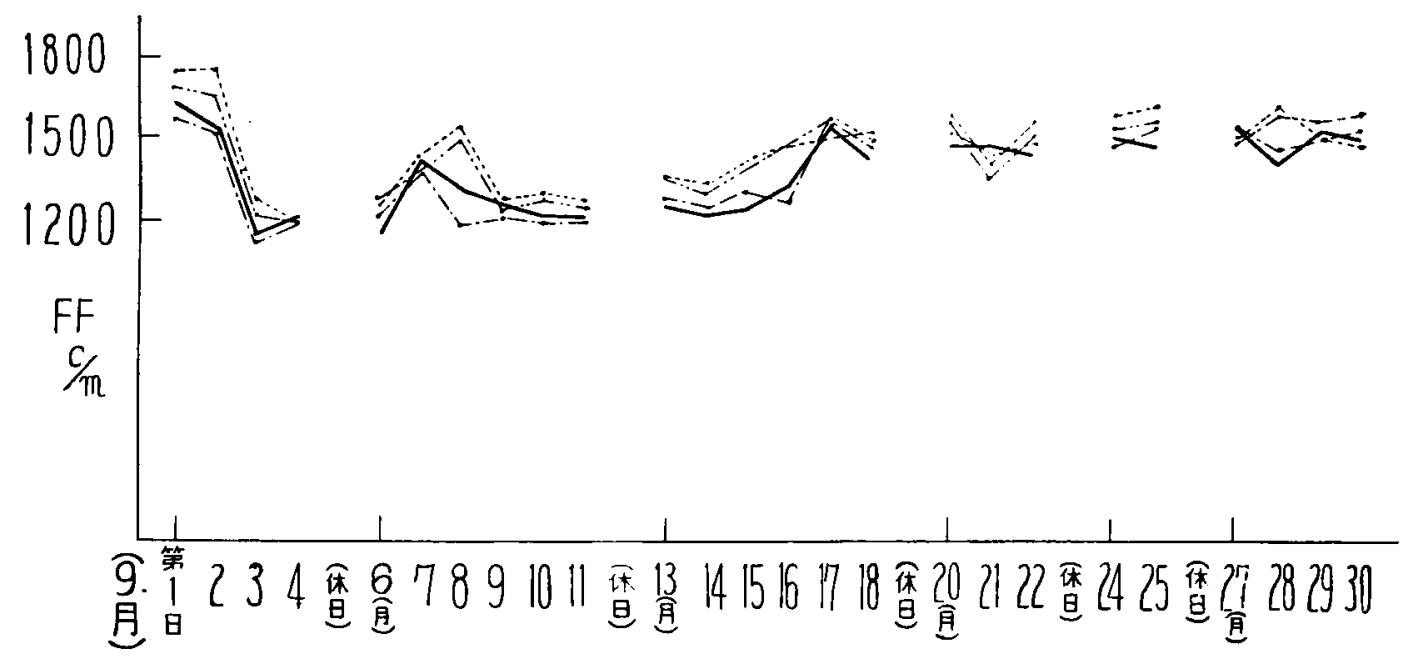

て平均値の差の検定を行つてみると，第 2 週と第 3 週， 第 3 週と第 4 週とはとるに有意な差があることがみら れ，第 4 週と第 5 週とについては有意ではなかつた(危险 率: $1 \%$ )。

II）日間変動と週間変動との関俰

第 1 作業日の $\mathrm{F}$ 值の日間变動と，第 1 作業日の作業前 ，值の週末の作業後值に対する变動の関保をみると ，第 2 図の如く，第 1 週の日間及び週間の変動はともに低下 を示し，第 2 週に入り週間の変動は上昇をみ，日間の变 動は相半ばしている。第 3 週より第 4 週にかけて日間及 び週間の変動は固定の倾向を示している。

\section{III) F 值の逐日経過}

被㛟者 4 名について第 I 作業日の作業前值の経過を連 日(日曜・祭日を除く) 1 カ月にわたつてみた(第 3 図)。
これは第 1 作業日の作業前值を一心の基準としてみた。 結局新しい困難と考えられる作業にとりかかる場合の大 脳の態度とい5るのを示している。

F值の経過をみれば，第1週の第3〜第 4 日に低下著 しく，第 2 週目に入り第 7 ～第 8 日にやや上昇を示し， 第 9 日から第 15 日（ 3 週目）に至り漱次上昇し，第 17 日 ないし第 4 週の第 20 日目（月曜日）から第 1 作業日の值： に近つきを示している。

一般に約 3 週間にして慣れの状態に入り，いわば痕学 の恢復がみられる。

\section{第 4 章 粉括並ひに考揬}

著者は， F値の作業前後の变動の逐日的変化を，昼間 事務勤移者が依間授業を課せられてからそれに慣れるま 
での期間にわたつてみた。

1) 作業前 F 值の週間变動圷第 2 週目に低下著しく， 第 3 週目より上昇しはじめ，第 4 週・第 5 週に至つて定 常状態を示しているとみられる。

2) F 值の日間变動と週間变動との関係

$\mathrm{F}$ 值の作業前後の変動と，第 1 作業日の前値と週末の 作業後值に対する变動との関係をみてを，第 3 週より低 下が借かで，漸次上昇の倾向を示している。第 4 週上り 惯れの状態即ち恢復過玨がるれる。

3) F值の逐日経過

F値の作業第 1 日の作業前値の逐日経過をみた。生活 状態及さ作日效香等により若干の变動をみるが，全般的 に授業開始後第20日目頃から恒常に戻る傾向を示して いる。

昼間の作業事秝より新しく夜間授業に従事し，仕事の 慣れとともにF值の恒常に戻るのが約 3 週間にして来る ことがみられた。

\section{第 5 章 結 語}

定時制女子高校生にして屋間事䅂勤称者たる被検者達 につき，新学期に入り夜間授業を課せられつつある時の 疲労の逐日経過を観察すへく F值の变動をみた。

1） $\mathrm{F}$ 值の 週間変動をみれば第 2 週目に著しく低下 し，漸次上昇を示し，第 4 週目より恒常状態に戾りはじ $\$ z$ :

2）日間变勤と週間変動との関係は，第 1 週に低下著
しく，第3週目よりその变動む僅かで，第 4 週目より但 常に戻りはじめる傾向にある。

3） $\mathrm{F}$ 值の逐日経過を約 1 カ月にわたつてみれば，新 学期夜間授業開始後第 20 日目頃 (約 3 週目) 上り恒常に 戻る倾向をみた。

稿を終るに当り，御朢篤なる御指導並びに御校閲を晹 わりました恩師安倍弘毅教授に梁く感謝致します。

\section{文献}

1）八木高次：生座明線に関する研究(その三)，労 働科学研究， 3 巻， 3 号，大 15.

2) 桐原保見： 1 週間作業明線儿就て, 労䡃科学研 究, 6 堂, 3 号, 昭 4 .

3) 大皂正光：ちらつき值の融什!照非度を以てす

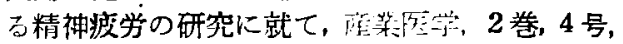
昭 24.

4) 大島正光：閃光融合閾測定法についての吟味, 労働の科学, 25 巻, 3 号, 昭 25 .

5）石川元雄：疲労々其の対策，昭 26 .

6) 日本労研：産業疲労蚞查の方法, 昭 27 .

7) 日本応㤔心理学会：心理学满座，8巻，IV, 昭 28.

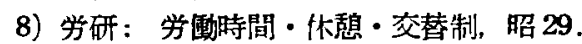

9）スネデカー：統㹬的方法(上)，昭 29 .

10) Hollingworth : Variations in Efficiency during the Working Day. Psychol. Rev., 1914.

11) Hours of Work and Efficiency (Nature, Vol. 146, No. 3691, 1940).

（受付：1955年 4 月 27 日) 